\begin{tabular}{|l|l|l||}
\hline \multicolumn{2}{|c|}{ PublisherInfo } \\
\hline \hline PublisherName & $:$ & BioMed Central \\
\hline \hline PublisherLocation & $:$ & London \\
\hline \hline PublisherImprintName & $:$ & BioMed Central \\
\hline \hline
\end{tabular}

\title{
Duration of adjuvant tamoxifen treatment
}

\begin{tabular}{|l|l|l||}
\hline \multicolumn{2}{|c|}{ ArticleInfo } \\
\hline \hline ArticleID & $:$ & 3774 \\
\hline \hline ArticleDOI & $:$ & $10.1186 /$ bcr-2001-68461 \\
\hline \hline ArticleCitationID & $:$ & 68461 \\
\hline \hline ArticleSequenceNumber & $:$ & 46 \\
\hline \hline ArticleCategory & $:$ & Paper Report \\
\hline \hline ArticleFirstPage & $:$ & 1 \\
\hline \hline ArticleLastPage & $:$ & 3 \\
\hline \hline & & RegistrationDate $: 2001-8-20$ \\
ArticleHistory & $:$ & Received \\
& Accepted 2001-5-17 & $:$ 2001-8-20 \\
\hline \hline ArticleCopyright & $:$ & Biomed Central Ltd2001 \\
\hline \hline ArticleGrants & $:$ & \\
\hline \hline
\end{tabular}




\begin{tabular}{|l|l|l|l|}
\hline ArticleContext & $:$ & 1305833 \\
\hline
\end{tabular}

Fatima Cardoso, ${ }^{\text {Aff1 }}$

Aff1 Jules Bordet Institute, Brussels, Belgium

\section{Keywords}

\section{Context}

The benefits of adjuvant tamoxifen are indisputable; however, its optimal duration is an issue still under discussion. The Oxford Overview analysis, based on 35,000 patients, concludes that five-year treatment is clearly superior to $0-2$ years of treatment. Whether a longer period of therapy, namely 10 years, can yield better results is still unknown as the number of patients enrolled in clinical trials (8000) and the median follow-up are still insufficient. Furthermore, the benefits must always be balanced with its potential hazards, namely the increased risk of endometrial cancer that could be related to the duration of therapy. This study investigated the effects of drug treatment after relapse or surgical/ radiological treatment.

\section{Significant findings}

Two major conclusions were drawn. First, the beneficial effects of five years of adjuvant tamoxifen are maintained through at least 15 years, in terms of overall survival $(P=0.006)$, death from breast cancer $(P=0.002)$, and systemic relapse $(P=0.007)$. Second, no additional benefit, in survival or freedom from recurrence, was observed in those patients who were randomly assigned to take tamoxifen more than five years.

\section{Comments}

This trial confirms the importance of this therapy and the notion that the protective effect of adjuvant tamoxifen is prolonged for many years beyond the completion of treatment. Although a relatively small 
number of patients received tamoxifen for more than five years, the absence of benefit is in concordance with the findings of the larger National Surgical Breast and Bowel Project trial published in 1996 (see Additional information), and will certainly contribute to the next evaluation of the Oxford meta-analysis. One weakness of this trial is the low percentage of patients with known oestrogen receptor status $(57 \%)$ and its method of determination.

\section{Methods}

Kaplan-Meir (survival curves), two-tailed log-rank test (statistic significance), Cox proportional hazard models $(95 \%$ confidence intervals)

\section{Additional information}

Fisher B, Dignam J, Bryant J, DeCillis A, Wickerham DL, Wolmark N, Costantino J, Redmond C, Fisher ER, Bowman DM, Deschenes L, Dimitrov NV, Margolese RG, Robidoux A, Shibata H, Terz J, Paterson AH, Feldman MI, Farrar W, Evans J, Lickley HL: Five versus more than five years of tamoxifen therapy for breast cancer patients with negative lymph nodes and estrogen receptorpositive tumors. J Natl Cancer Inst 1996, 88:1529-1542 (PubMed abstract).

\section{References}

1. Stewart HJ, Prescott RJ, Forrest APM: Scottish adjuvant tamoxifen trial: a randomized study updated to 15 years. J Natl Cancer Inst. 2001, 93: 456-462. 